\title{
Effects of large-scale advective processes on gelatinous zooplankton populations in the northern Benguela ecosystem
}

\author{
F. Pagès, J. M. Gili \\ Institut de Ciències del Mar (CSIC), Passeig Nacional s/n, E-08039 Barcelona, Spain
}

\begin{abstract}
In April 1986 a strong intrusion of Angolan waters into the northern part of the Benguela system coincided with an abatement in the upwelling activity that characterizes the region. This important advective process facilitated penetration by large numbers of species and individuals of the gelatinous zooplankton, chiefly siphonophores and hydromedusae. The increased densities in turn were reflected in higher concentration levels and greater diversity in the populations of planktonic cnidarians than are usually generated by the region's upwelling activity. The most conspicuous result was a pronounced latitudinal (north-south) gradient that was clearly detectable above the thermocline, though the effect of the hydrographic event tapered off with depth. The consequences on upwelling regions of interannual events of the scope of that considered here are discussed in relation to the biological characteristics of the siphonophores and medusae.
\end{abstract}

\section{INTRODUCTION}

Advective processes involving the transport of large masses of water are, together with eddies and changes in local circulation patterns, one of the primary causes of alterations in coastal ecosystems (Denman \& Powell 1984). Interannual changes in atmospheric conditions and in the pattern of oceanic currents in general would appear to be responsible for strong intrusions of allochthonous water masses or changes in current intensity. Mesoscale physical processes like these can be expected to bring about changes on the same scale in biological processes in coastal regions (Haury et al. 1978). Thus, interannual changes in the California Current have been observed to give rise to unusually high influxes of cold, nutrient-rich water inshore in spring (Hickey 1979); while these waters remain over the shelf, important changes take place in the structure of zooplankton populations and can bring about substantial increases in biomass (Bernal 1981, Chelton et al. 1982). In this regard, Bernal \& McGowan (1981) reported that the resulting advective process exerted a greater positive influence on the zooplankton than did upwelling in the area. Situations similar to those described for the California Current have been reported in the vicinity of Vancouver (Freeland \& Den- man 1982) and off Somalia (Bruce 1979), where intrusions of water masses borne by currents whose intensity varied on an interannual basis have been recorded and have resulted in increases in zooplankton biomass. Within zooplankton populations, species belonging to the gelatinous zooplankton are good indicators of recent mesoscale hydrographic events. Raymont (1983) provided numerous examples of species regarded as indicators (in the context developed by Russell 1935) of water masses of varying characteristics; most of these species were gelatinous zooplankton. Colebrook (1977) corroborated this in his study of the spatial distribution of different zooplankton groups over several years in the California Current region. The spatial distribution of groups like siphonophores, medusae, ctenophores, thaliaceans, etc., displayed a pronounced north-south gradient related principally to fluctuations in intensity of the Cahfornia Current. Thus, hydrographic events such as mesoscale advective processes have been considered responsible for the zoogeographic gradients observed in various systems, like that in the California Current region (e.g. Alvarin̄o 1964, Berner 1967, McGowan 1967) and the northern part of the Benguela Current system (Olivar 1990).

The latter system displays strong upwelling activity from March to November, although localized upwelling 
occurs all year long (Shannon 1985). Intrusions of warmer, more saline Angolan water take place in the northernmost part of the region (between 17 and $20^{\circ} \mathrm{S}$ ), which is influenced by the Benguela Current; such intrusions are subject to considerable interannual variation (Shannon et al. 1986). In years when atmospheric conditions in the South Atlantic are favourable, the intrusions can be very extensive, and the situation has been described as comparable to the El Niño phenomenon off Peru (Shannon et al. 1986). The effects of this situation on the zooplankton communities in the northern part of the Benguela system have remained largely unknown. Fearon et al. (1986) reported high zooplankton concentrations associated with a large mass of more saline water located near the border between Namibia and Angola. Their study was carried out in 1985; however in April 1986 the influx of Angolan water off northern Namibia was much greater than in preceding years (Boyd et al. 1987). The effects of this phenomenon on the zooplankton communities in the northern Benguela system have, for the most part, remained undescribed. Moreover, the role played by components of the gelatinous zooplankton in this system is one of its lessknown aspects (Shannon \& Pillar 1986). The present paper considers the impact of a major mesoscale hydro-

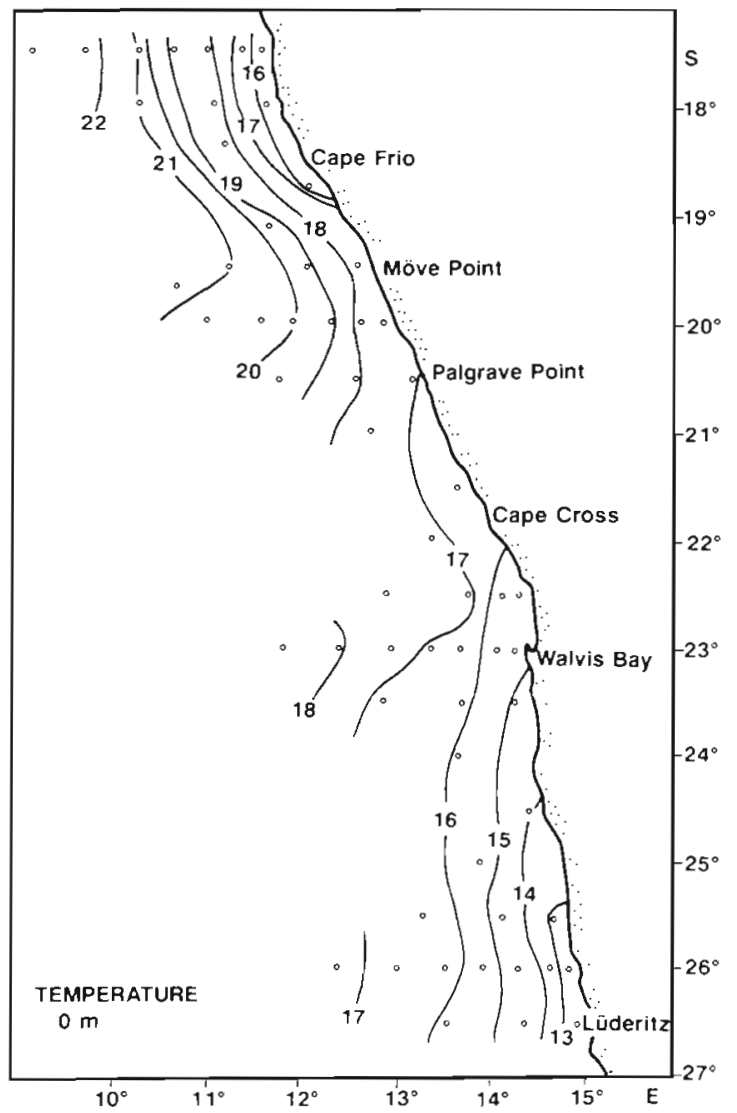

graphic event, i.e. an intrusion by Angolan water, on the gelatinous zooplankton in the northern Benguela region.

\section{MATERIAL AND METHODS}

The northern Benguela system was studied on the second Spanish Namibian Enviromment Cruise (SNEC II) from 10 to 23 April 1986. The survey was carried out over the continental shelf off Namibia between the Cunene River $\left(17^{\circ} 15^{\prime} \mathrm{S}\right)$ and Lüderitz $\left(26^{\circ} 30^{\prime} \mathrm{S}\right)$. A total of 61 stations were sampled using a multiple opening and closing Rectangular Midwater Trawl $1 \times 6$ net (mesh size $200 \mu \mathrm{m}$ ). Five depth strata (200 to 100,100 to 60,60 to 40,40 to 20 , and 20 to $0 \mathrm{~m}$ ) were sampled by oblique hauls at a mean towing speed of $0.35 \mathrm{~m} \mathrm{~s}^{-1}$. Flow was estimated by means of a calibrated digital flowmeter mounted centrally in the mouth of each of the five $200 \mu \mathrm{m}$ mesh nets. All zooplankton samples were preserved in borax-buffered, $5 \%$ formalin. Because a considerable proportion of the samples from the uppermost depth strata were mixed due to net malfunction, the present paper considers only 3 depth intervals, namely, 200 to 100,100 to 40 , and 40 to $0 \mathrm{~m}$. At each station temperature and salinity data were

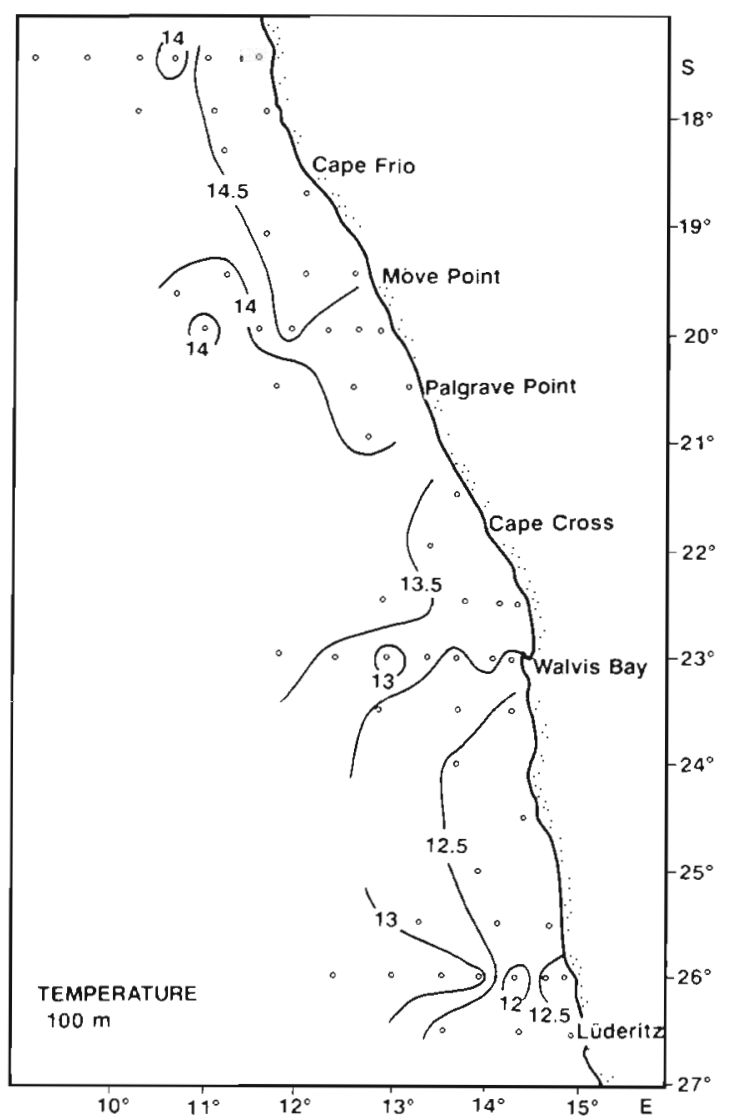

Fig. 1 Distribution of temperature values $\left({ }^{\circ} \mathrm{C}\right)$ at the surface and at $100 \mathrm{~m}$ depth in the northern Benguela region during the oceanographic survey carried out in April 1986. () Sampling station 
generally obtained at $5 \mathrm{~m}$ intervals in the upper $200 \mathrm{~m}$ by means of a calibrated CTD probe, with simultaneous sampling of the water column at various depths using a rosette system. CTD casts were carried out in conjunction with the zooplankton samples.

Siphonophores and medusae were the dominant gelatinous zooplankton in the samples. All individuals (both eudoxid and polygastric siphonophores were considered) of all species captured were counted and the counts standardized to number of individuals per $1000 \mathrm{~m}^{3}$ of water, based on the actual volume of water filtered through the net during each tow. As suggested by Pugh (1984), the numbers of physonects and hippopodiids present in the samples were divided by 10 to approximate the actual number of colonies sampled.

To obtain an objective indication of the distribution pattern of the siphonophore and medusan populations, principal component analysis (PCA) (Legendre \& Legendre 1979) was applied to the data for each depth stratum considered. PCA was performed on the species correlation matrix after smoothing of the data by logarithmic transformation. A Spearman rank correlation (Conover 1980) between the factor scores for the stations and the mean temperature and salinity values was run for each of the 3 depth intervals, to furnish the required information on the relationship between these 2 hydrographic factors and the distribution pattern for each of these zooplankton populations.

\section{RESULTS}

The hydrographic situation over the continental shelf off northern Namibia in April 1986 was characterized by a strong intrusion of Angolan water. This water was warmer and more saline and gave rise to a marked latitudinal gradient in temperature and salinity distribution patterns. In fact, temperatures differed from north to south by more than $10 \mathrm{C}^{\circ}$ in the surface layers but only by $2 \mathrm{C}^{\circ}$ at most at a depth of ca $100 \mathrm{~m}$ (Fig. 1). As a consequence of this temperature gradient, the thermocline, which was located at a depth of about $40 \mathrm{~m}$, was much stronger in the northern than in the southern half of the study area (Salat et al. 1991). The pattern of salinity values was similar to that for temperature, with higher values in the northern half of the area and a weaker gradient at depths below $100 \mathrm{~m}$ (Fig. 2). Masó (1987) presented results from 4 transects
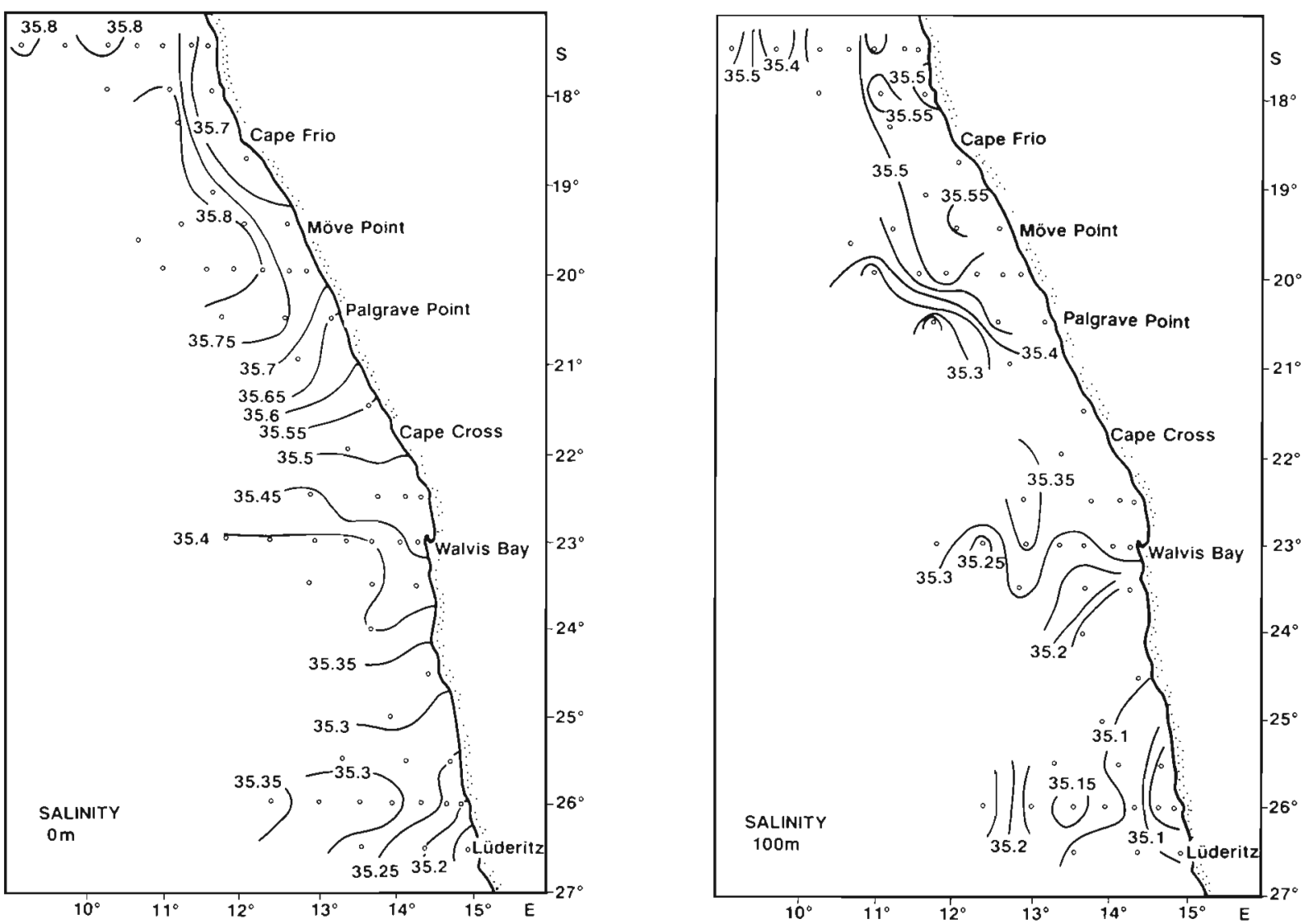

Fig. 2. Distribution of salinity values (\%) at the surface and at $100 \mathrm{~m}$ depth in the northern Benguela region during the oceanographic survey carried out in April 1986. () Sampling station 

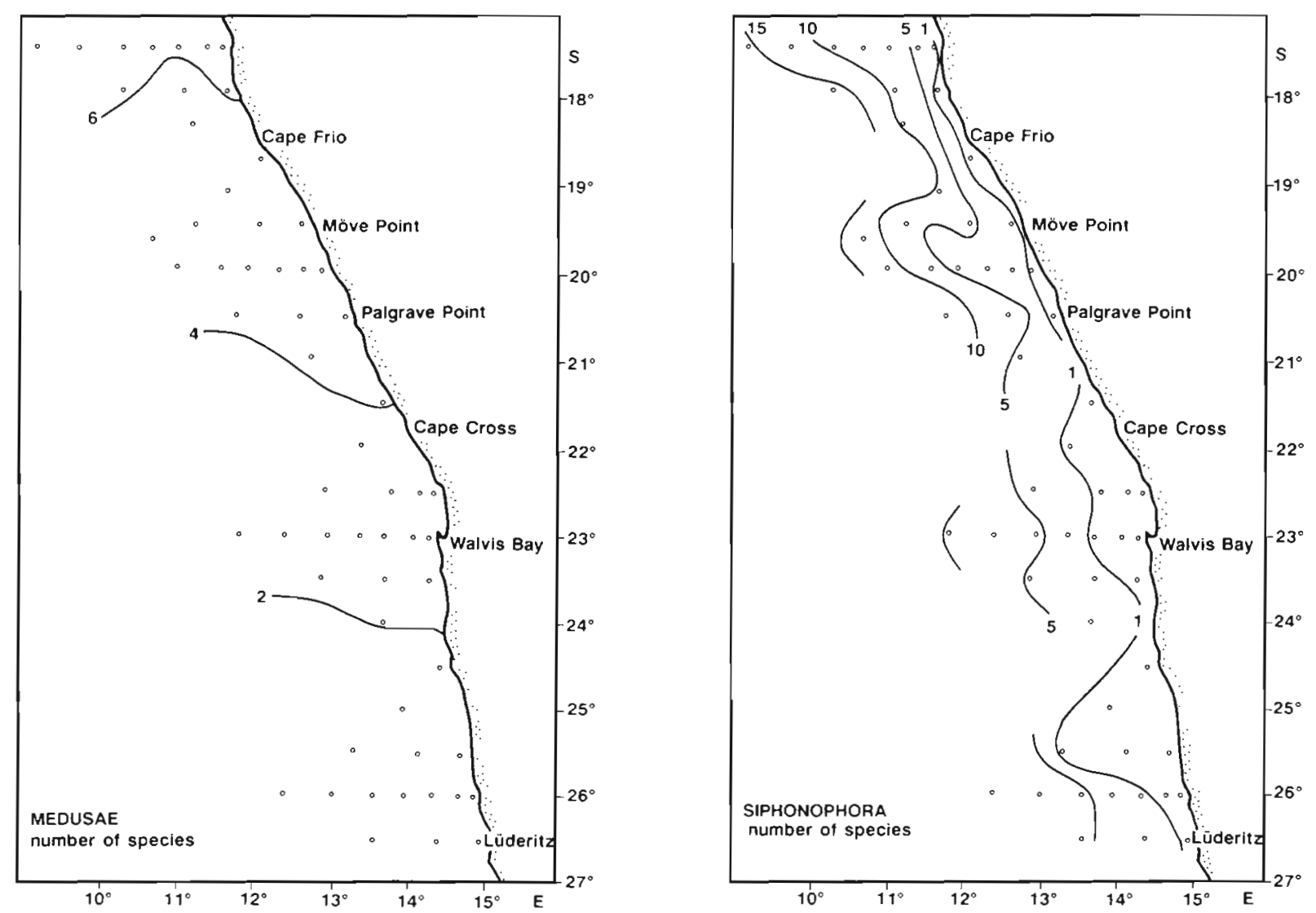

Fig. 3. Distribution pattern of number of species per station (200 to $0 \mathrm{~m}$ ) for medusae and siphonophores collected during the oceanographic survey carried out in April 1986. () Sampling station

extending across the shelf during the SNEC II cruise, located at $18,20,23$ and $26^{\circ} \mathrm{S}$. She showed that a strong surface-temperature gradient existed in the northern part of the area, while the vertical temperature gradient was weaker southward. Waters were strongly stratified offshore and northwards, with a thermocline between 40 and $50 \mathrm{~m}$ depth.

A total of 31 species of medusae and 35 species of siphonophores were identified. The number of species per station increased latitudinally from south to north (Fig. 3), with the siphonophores exhibiting a weak inshore-to-offshore gradient. To simplify the distribution pattern for the siphonophores and medusae, the mean density of each species was calculated for each of the 3 depth strata considered and for 3 geographic subareas: a northern $\left(17^{\circ} 15^{\prime}\right.$ to $\left.20^{\circ} \mathrm{S}\right)$, a central $\left(20^{\circ}\right.$ to $23^{\circ} \mathrm{S}$ ), and a southern $\left(23^{\circ}\right.$ to $26^{\circ} 30^{\prime} \mathrm{S}$ ) (Tables $1 \& 2$ ).

For both siphonophores and medusae the highest number of species was encountered in the surface layer above $40 \mathrm{~m}$ depth (Tables $1 \& 2$ ) and the number of species at the depth intervals 100 to 40 and 200 to $100 \mathrm{~m}$ was significantly lower ( $p<0.05$, Student's $t$-test). The number of individuals present in the southern sub-area was significantly lower than in the central and northern sub-areas, for both medusae and siphonophores $(p<$ 0.01 ). The concentration of individuals was similar and not significantly different $(p>0.05)$ in the 0 to $40 \mathrm{~m}$ depth interval of the central and northern sub-areas, but in the central sub-area a few species were responsible for these counts. The number of species was significantly higher in the northern sub-area than in the central $(p<0.05)$ and southern sub-areas $(p<0.01)$.

The main medusan species in the southern sub-area, i.e. Podocoryne sp., Bougainvillia macloviana, Clytia simplex, and Proboscidactyla menoni, dwell close to the shore and have a polyp stage; individuals of these species tended to display high concentrations at a very few stations. In the central sub-area, concentrations of the species that were most abundant throughout the entire study area, i.e. Aglaura hemistoma and Mitrocomella grandis, were present both inshore and over the continental shelf. In the northern sub-area species that were more oceanic in nature predominated, and these exhibited a broad distribution in the upper $100 \mathrm{~m}$ of the water column (Table 1).

The distribution pattern of siphonophores was rather similar to that of the medusae, yet there were also important differences. The species in the southern sub- 


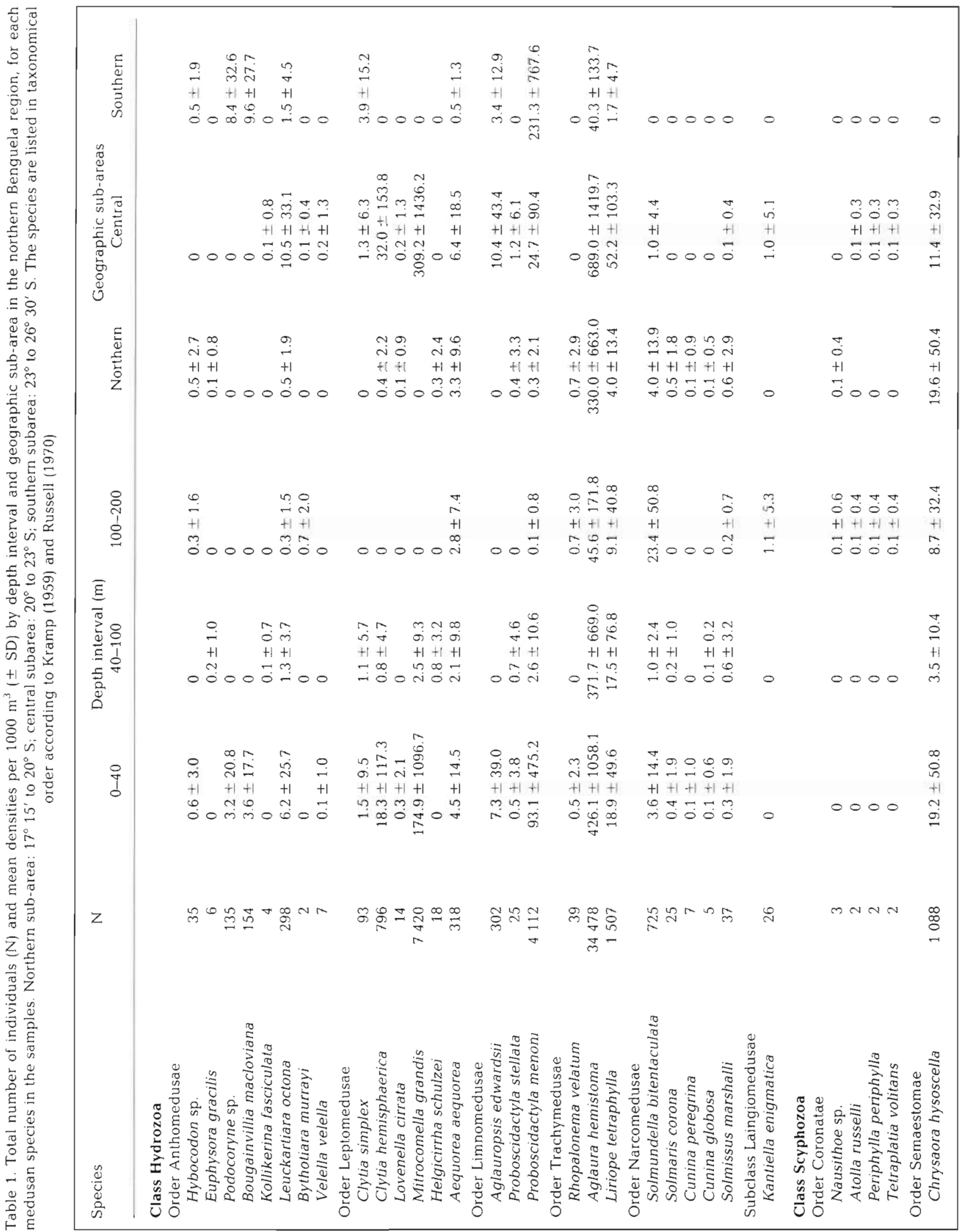




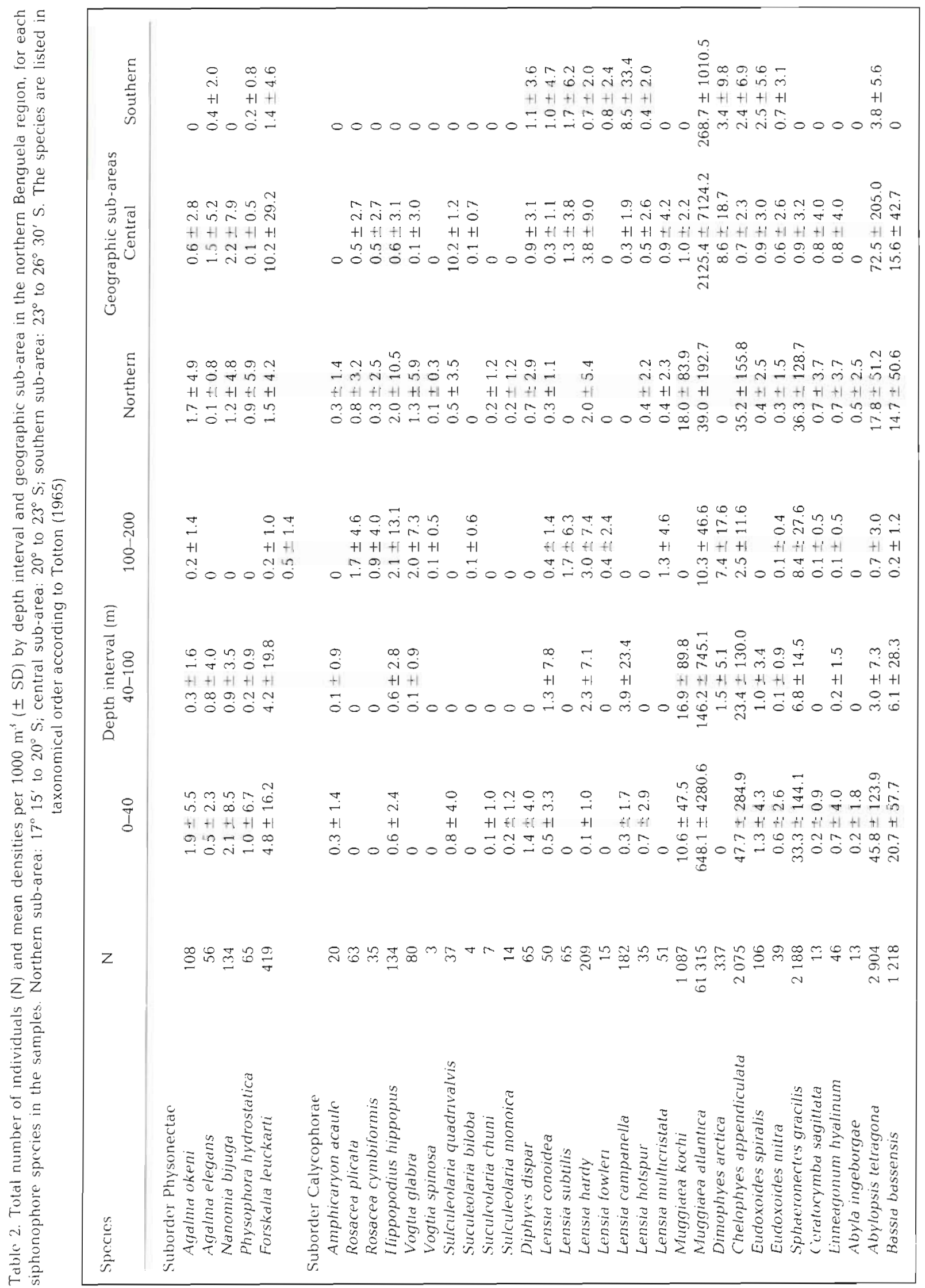



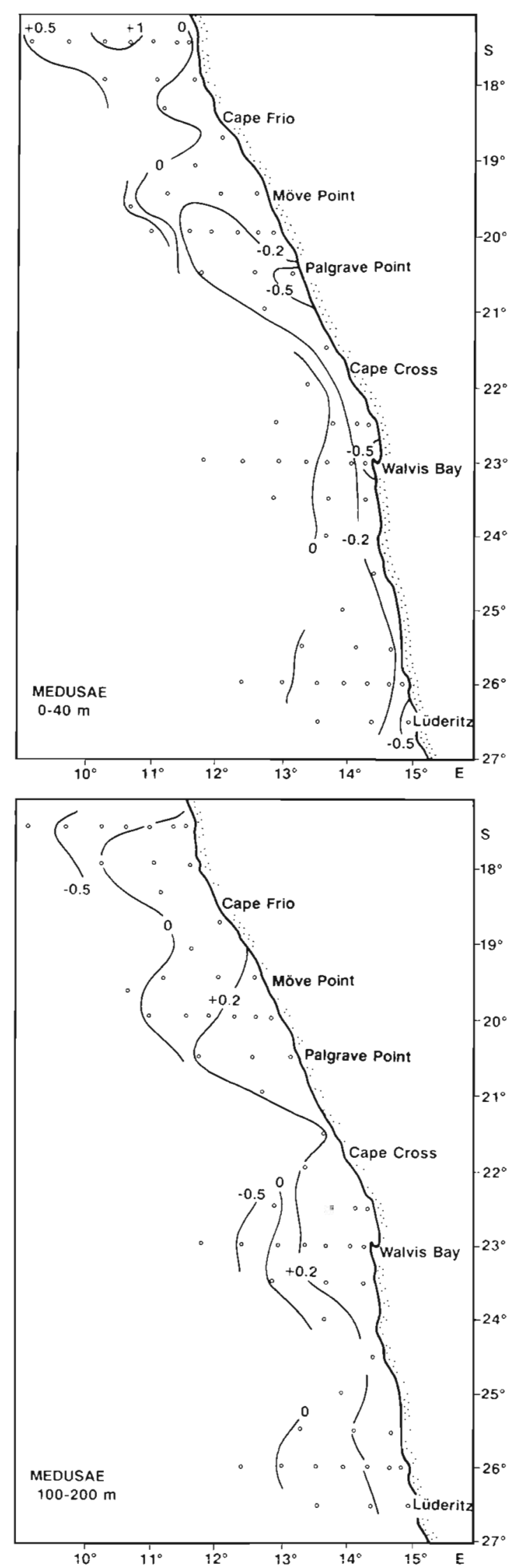

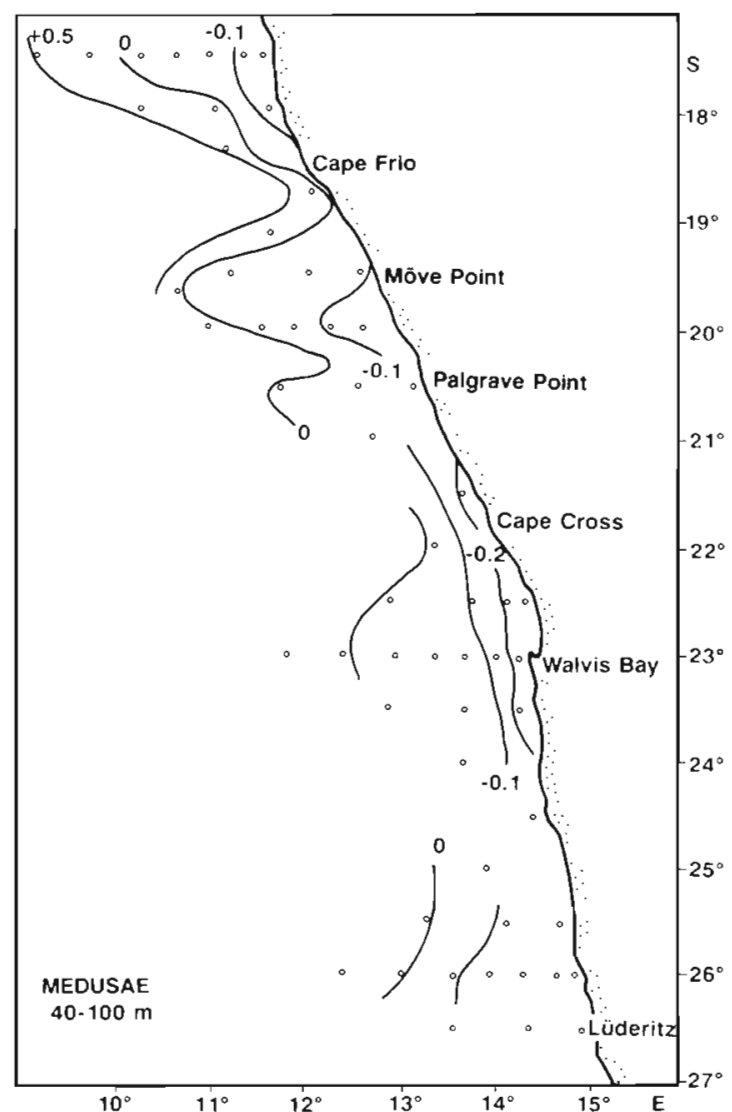

Fig. 4. Distribution of factor score values for Factor 1 from principal component analysis (PCA) for each depth interval considered ( 0 to 40,40 to 100 , and 100 to $200 \mathrm{~m}$ ) for the medusan population. The positive f-score values correspond to high concentrations of individuals and large numbers of species, whereas the negative values correspond to low concentrations of individuals and small numbers of species. () Sampling station

area, such as Lensia fowleri and Dimophyes arctica, tended to dwell in deep water offshore. The most abundant species in the study area, i.e. Muggiaea atlantica, formed dense aggregations in the central sub-area, preferably close to the surface inshore. Conversely, in the northern sub-area the species were more oceanic and the vertical distribution range was broader.

The factor scores for the first PCA factor have been plotted for both medusae (Fig. 4) and siphonophores (Fig. 5) in each of the 3 depth strata considered. The northern offshore locations, containing the highest concentrations of individuals and species, are contrasted along the first factor of the PCA with the southern inshore locations, containing low concentrations of individuals and species. These results show a north-south segregation of species in both groups within the study area. For both groups the latitudinal change was most marked in the surface layer, clearly discernible in the layer below the thermocline, and barely perceptible in the layer deeper 

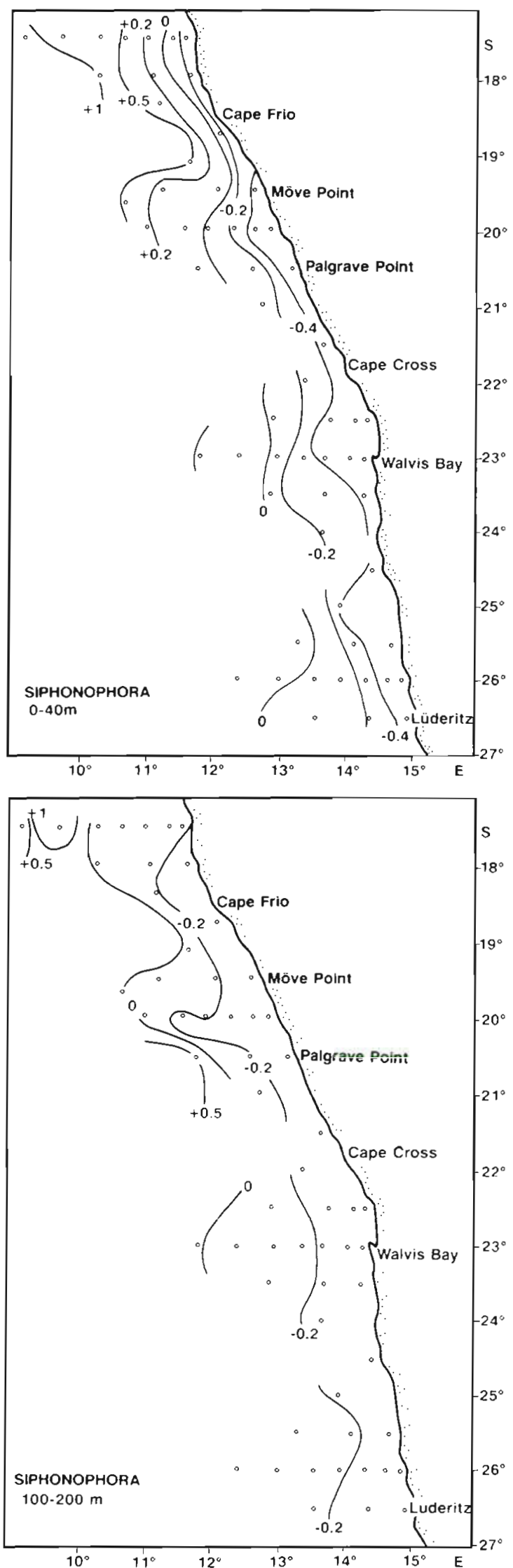

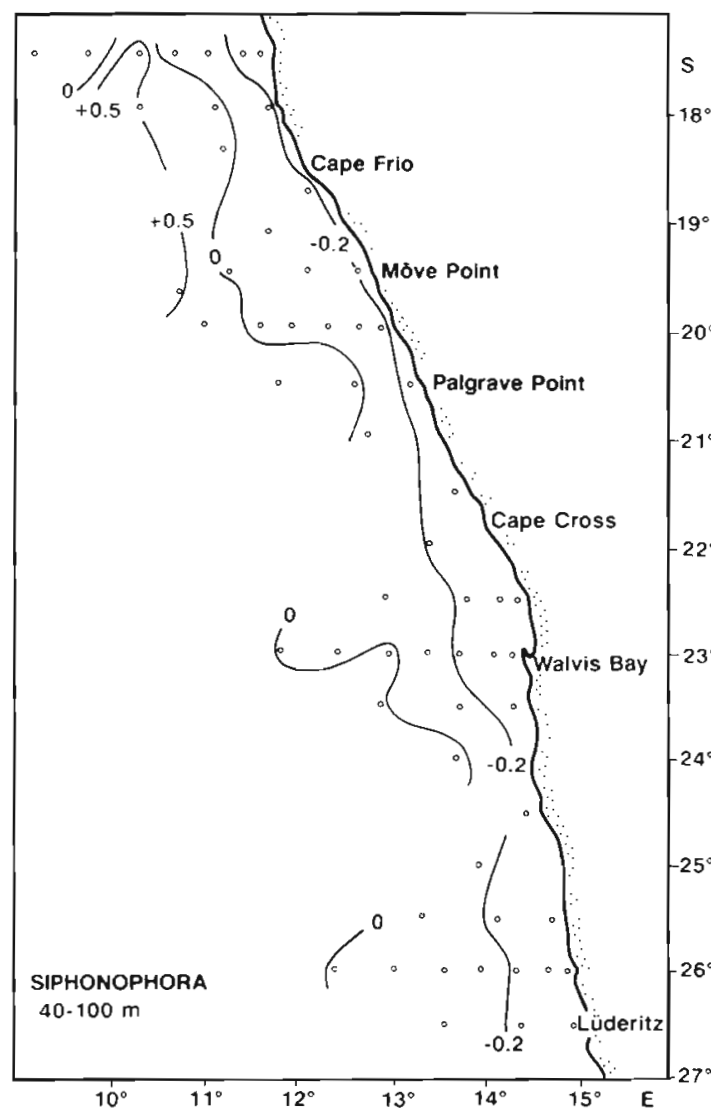

Fig. 5. Distribution of $\mathrm{f}$-score values for Factor 1 from principal component analysis (PCA) for each depth interval considered ( 0 to 40,40 to 100 , and 100 to $200 \mathrm{~m}$ ) for the siphonophore population. The positive f-score values correspond to high concentration of individuals and large numbers of species, whereas the negative values correspond to low concentrations of individuals and small numbers of species. () Sampling station

than $100 \mathrm{~m}$. The presence of more oceanic species in this deepest stratum made the effect of inshore-offshore differentiation more pronounced than the north-south segregation effect. The trends observed for each of the groups of organisms in each of the 3 depth intervals were significantly correlated with the trends recorded for the hydrographic factors (Table 3). The spatial distribution of temperature values in the uppermost layer was significantly correlated with the distribution patterns of the populations of both zooplankton groups considered. The correlation coefficients for both groups decreased with depth and were not significant in all cases in the 200 to $100 \mathrm{~m}$ depth stratum.

\section{DISCUSSION}

Coastal systems are made up of a variety of hydrographic mechanisms that act in varying degrees on the 
Table 3 Spearman rank correlation between the factor scores for factor 1 from principal component analysis (PCA) and the mean temperature and salinity values by depth interval, for both medusae and siphonophores

\begin{tabular}{|c|c|c|c|c|}
\hline & & $\begin{array}{l}\text { PCA } \\
\text { axis } 1\end{array}$ & $\begin{array}{l}\text { Temper- } \\
\text { ature }\end{array}$ & Salinity \\
\hline \multicolumn{5}{|l|}{ Medusae } \\
\hline \multirow[t]{3}{*}{$0-40 \mathrm{~m}$} & PCA axis 1 & 1 & & \\
\hline & Temperature & $0.54^{\cdots}$ & 1 & \\
\hline & Salinity & $0.45^{\cdots}$ & $0.79 \cdots$ & 1 \\
\hline \multirow[t]{3}{*}{$40-100 \mathrm{~m}$} & PCA axis 1 & 1 & & \\
\hline & Temperature & $0.43^{\circ}$ & 1 & \\
\hline & Salinity & $0.38^{\circ}$ & $0.84^{\cdots}$ & 1 \\
\hline \multirow[t]{3}{*}{$100-200 \mathrm{~m}$} & PCA axis 1 & 1 & & \\
\hline & Temperature & 0.25 & 1 & \\
\hline & Salinity & 0.13 & $0.84^{\cdots}$ & 1 \\
\hline \multicolumn{5}{|c|}{ Siphonophora } \\
\hline \multirow[t]{3}{*}{$0-40 \mathrm{~m}$} & PCA axis 1 & 1 & & \\
\hline & Temperature & $0.70^{\circ}$ & 1 & \\
\hline & Salinity & $0.49^{\circ}$ & $0.79^{\circ} \cdot$ & 1 \\
\hline \multirow[t]{3}{*}{$40-100 \mathrm{~m}$} & PCA axis 1 & 1 & & \\
\hline & Temperature & $0.52^{\circ}$ & 1 & \\
\hline & Salinity & $0.42^{\circ}$ & $0.84^{\cdots}$ & 1 \\
\hline \multirow[t]{3}{*}{$100-200 \mathrm{~m}$} & PCA axis 1 & 1 & & \\
\hline & Temperature & 0.28 & 1 & \\
\hline & Salinity & 0.15 & $0.84^{\cdots}$ & 1 \\
\hline
\end{tabular}

zooplankton populations. In upwelling areas like the Benguela system, in which environmental conditions are highly unstable (Hart \& Currie 1960), physical events are responsible for the variability in species abundance and distribution (McGowan 1974). Actually, the physical mechanisms that regulate the spatiotemporal heterogeneity of zooplankton tend to be mesoscalar (Denman \& Powell 1984), especially in the case of the gelatinous plankton, which are considerally dependent upon the dynamics of water masses. In this respect the northern part of the Benguela system is strongly influenced by the hydrographic mechanisms associated with upwelling in the region located between 22 and $24^{\circ} \mathrm{S}$. The highest concentrations of zooplankton, with extremely dense populations but low diversity, have been reported just to the north of this upwelling centre (Kollmer 1963, Unterüberbacher 1964). The notion that zooplankton in upwelling areas exhibit high concentrations but low diversity has existed for some time (see, for example, Thiriot 1978). However, the gelatinous zooplankton do not seem to conform to the pattern characterizing other zooplankton, and Shannon \& Pillar (1986) even reported highly diverse zooplankton populations consisting chiefly of gelatinous plankton at the edge of the area of most active upwelling in the northern Benguela region.

The concentrations and distribution patterns of siphonophores and medusae recorded in the northern part of the Benguela system in April 1986, and the pattern indicated by PCA, were the result of mesoscale hydrographic processes associated with upwelling activity in the region. Boyd et al. (1987) and Salat et al. (1991) have reported the unique hydrographic conditions that prevailed in April 1986 to be a result of a relative abatement in upwelling in the preceding months, although upwelling remained active, as evidenced by the high chlorophyll values that were recorded inshore between 22 and $24^{\circ} \mathrm{S}$ (Estrada \& Marrasé 1987 ). The most important feature was the exceptionally strong intrusion of Angolan water that started along the edge of the continental shelf and subsequently moved inshore, finally falling off around $19^{\circ} \mathrm{S}$. This Angolan water was clearly detectable down to a depth of $50 \mathrm{~m}$, and its effects could be detected down to $100 \mathrm{~m}$. Analysis of the geostrophic flow rates in the region has demonstrated the presence of a frontal zone north of $22^{\circ} \mathrm{S}$, where the Angolan water (flowing from north to south) came into contact with the Benguela water (flowing from south to north). This frontal zone was caused in part by an anticyclonic gyre located off Walvis Bay, which appeared to combine with the intrusion of Angolan water to form a barrier, giving rise to a retention zone in the area (Salat et al. 1991).

The more superficial Angolan water contributed to the formation of a latitudinal gradient in the zooplankton populations studied. The influence of the Angolan water decreased with depth concomitantly with the decrease in intensity of the north-south gradient in the gelatinous zooplankton. At depths greater than $100 \mathrm{~m}$, which were relatively unaffected by the penetration of water from the north, the inshore-offshore gradient resembled the typical spatial distribution of zooplankton in upwelling areas, in which maximum concentration values usually occur inshore and fall off rapidly offshore (Andrews \& Hutchings 1980). Moreover, recent studies carried out along the Namibian coast during a 4 mo upwelling-downwelling period showed a clear and constant coastal-offshore gradient of species and individuals along the entire Namibian shelf (Pagès unpubl.). The possible retention zone associated with the frontal zone exhibited dense populations of both siphonophores and medusae, coupled with low diversity. Certain species, like Aglaura hemistoma, Liriope tetraphylla, Muggiaea atlantica, Abylopsis tetragona, and some species of the genus Lensia, formed dense populations in the study area. These species tend to be cosmopolitan and are common in upwelling regions (Thiriot 1978). In fact, these species can exhibit very high concentrations of individuals inshore, where environmental conditions are least stable (see, for instance, Goy \& Thiriot 1974 and Gili et al. 1988). 
The number of species recorded, especially for siphonophores, was comparable to the values recorded in tropical regions (Pugh 1974), inasmuch as the number of species collected in just $2 \mathrm{~d}$ at a single survey station located 60 miles off the Cunene River mouth was quite similar to that found in the present study (Pagès \& Gili 1991). These concentration values were higher than those that could have been produced solely by the upwelling regime in the region (up to 24 species were collected from December 1981 to March 1982; Pagès unpubl.) and were similar in scope to those reported by Colebrook (1977) during a period of increased California Current intensity. Similar phenomena, in which latitudinal zooplankton gradients tended to reflect heavy penetration by allochthonous, and occasionally oceanic, water masses, have been reported in other upwelling regions (e.g. Bernal \& McGowan 1981, Santander 1981).

Many of the gelatinous zooplankton are carnivores and are important secondary consumers (Alldredge 1983, Larson 1987). In this regard the occurrence of unusually high concentrations of gelatinous zooplankton in a given area may have important repercussions for the remaining zooplankton. In fact, a concurrent study carried out off Namibia (Olivar \& Barangé 1990) reported substantially lower zooplankton biomass levels in the northern part of the region, coupled with much higher densities of copepods in the southern half. There was a significant negative correlation between the total number of copepods and the total numbers of siphonophores and medusae in the northern part of the area $(\mathrm{r}=-0.58, \mathrm{p} \leq 0.05)$. This zone of spatial exclusion might be indicative of a trophic interaction between these 2 groups, though no direct evidence is available. On the other hand, certain authors have explained this kind of correlation in different terms and have preferred to speak of differences in the distribution of predators and potential prey organisms in different water masses rather than of direct interaction (e.g. Frank \& Leggett 1982). Nevertheless, the fact that the density values for medusae, siphonophores, and copepods were all obtained from the same samples, coupled with the fact that certain of the species present (like Muggiaea atlantica, Sphaeronectes gracilis, and others) are heavy predators of copepods (Purcell 1982, Purcell \& Kremer 1983, Mackie et al. 1987), suggests that the warm-water event reported, here involving penetration by Angolan waters, may have had a considerable impact on the zooplankton in the northern Benguela region.

Applying the conceptual model for the Benguela system developed by Shannon (1985), the distribution pattern for the gelatinous zooplankton observed in April 1986 can be explained in terms of the following hydrographic mechanisms: a northward transport of inshore surface water from the area of maximum upwelling intensity, giving rise to the high zooplankton concentrations and low diversity levels in the vicinity of Walvis Bay; the convergence slightly to the north of Walvis Bay, which acted to maximize the aggregation process in this area; and penetration by warm Angolan water, augmenting both concentration and diversity levels in the northern part of the Benguela system. In any event, the intensity of the influx of Angolan water in April 1986 gave rise to a considerable alteration in the normal pattern, that yielded an unusually large zone of zooplankton aggregation compared to that produced solely by the normal regime of upwelling activity in the region. The major warmth anomalies in the northern Benguela apparently occur as a response to changes in atmospheric pressure at low latitudes and do not appear to be related to changes in local wind stress or local hydrographic features. These anomalies would originate in the north or northwest of the Benguela system and would drive interannual variability, most notably in gelatinous zooplankton, and possibly in all zooplankton.

Acknowledgements. We thank Dr E. Macpherson, Director of the programme 'The Study of Austral African Fisheries', which supported this work, and Dr M. P. Olivar for her help in processing the original data. Thanks are given to Dr A. Sabatés for her useful comments on the original manuscript, and also to $\mathrm{Mr} \mathrm{R}$. Sacks for help with preparation of the English draft.

\section{LITERATURE CITED}

Alldredge, A. L. (1983). The quantitative significance of gelatinous zooplankton as pelagic consumers. In: Fasham, M. J R. (ed.) Flows of energy and materials in marine ecosystems: theory and practice. Plenum Press, London, p. $407-433$

Alvariño, A. (1964). Zoogeografía de los Quetognatos, especialmente de la region de California. Ciencia (Mexico) 23: $51-74$

Andrews, W R. H., Hutchings, L. (1980). Upwelling in the southern Benguela. Prog. Oceanogr 9: 1-81

Bernal, P. A. (1981). A review of the low-frequency response of the pelagic ecosystem in the California Current. CalCOFI Rep. 22: 49-62

Bernal, P. A., McGowan, J. A. (1981). Advection and upwelling in the California Current. In: Richards, F. A. (ed.) Coastal upwelling. American Geophysical Union, Washington, D.C., p. 381-399

Berner, L. D. (1967). Distributional atlas of Thaliacea in the California Current region. CalCOFI Atlas 8: 1-322

Boyd, A. J., Salat, J., Masó, M. (1987). The seasonal intrusion of reletively saline water on the shelf off northern and central Namibia. In: Payne, A. I. L., Gulland, J. A., Brink, K. H. (eds.) The Benguela and comparable ecosystems. S. Afr. J. mar. Sci. 5: 1.07-120

Bruce, J. G. (1979). Eddies off the Somal coast during the southwest monsoon. J. geophys. Res. 84: 7742-7748

Chelton, D. B., Bernal, P. A., McGowan, J. A. (1982). Large- 
scale interannual physical and biological interaction in the California Current. J. mar Res. 40: 1095-1125

Colebrook, J. M. (1977). Annual fluctuations in biomass of taxonomic groups of zooplankton in the California Current, 1955-59. Fish. Bull. U.S. 75: 357-368

Conover, W. J. (1980). Practical nonparametric statistics. John Wiley \& Sons, New York

Denman, K. L., Powell, T M. (1984). Effects of physical processes on planktonic ecosystems in the coastal ocean. Oceanogr. mar. Biol. A. Rev. 22: 125-168

Estrada, M., Marrasé, C. (1987). Phytoplankton biomass and productivity of the Namibian coast. In: Payne, A. I. L., Gulland, J. A., Brink, K. H. (eds.) The Benguela and comparable ecosystems. S. Afr. J. mar. Sci. 5: 347-356

Fearon, J., Boyd, A. J., Kruger, I. (1986). The distribution and abundance of the dominant groups of epipelagic zooplankton off Namibia in January 1985 in relation to surface temperature, salinity and chlorophyll. Colln scient. Pap. int. Commn SE. Atl. Fish. 13: 215-227

Frank, K. H. Leggett, W. C. (1982). Coastal water mass replacement: its effect on zooplankton dynamics and the predator-prey complex associated with larval capelin (Mallotus villosus). Can. J. Fish. Aquat. Sci. 39: 991-1003

Freeland, H. J., Denman, K. L. (1982). A topographically controlled upwelling center off southern Vancouver Island. J. mar. Res. 40: 1069-1093

Gili, J. M., Pagès, F., Sabatés, A., Ros, J. D. (1988). Small- scale distribution of cnidarian populations in the western Mediterranean. J. Plankton Res. 10: 385-401

Goy, J., Thiriot, A. (1974). Distribution despèces planctoniques carnivores dans la région de l Atlantique marocain. Résultats des campagnes Cineca-Charcot I, II et III. Téthys 6: $291-302$

Hart, T J., Currie, R. I. (1960). The Benguela Current. 'Discovery' Rep. 31 123-298

Haury, L. R., McGowan, J. A., Wiebe, P. H. (1978). Patterns and processes in the time-space scales of plankton distributions. In: Steele, J. H. (ed.) Spatial pattern in plankton communities. Plenum Press, New York, p. 277-327

Hickey, B. M. (1979). The California Current System hypotheses and facts. Prog. Oceanogr. 8: 191-279

Kollmer, W. E. (1963). Notes on zooplankton and phytoplankton collections made off Walvis Bay. Investl Rep. mar. Res. Lab. S.W. Afr. 8: 1-25

Kramp, P. L. (1959). The Hydromedusae of the Atlantic Ocean and adjacent waters. Dana Rep. 46: 1-283

Larson, R. J. (1987). Trophic ecology of planktonic gelatinous predators in Saanich Inlet, British Columbia: diets and prey selection. J. Plankton Res. 9: 811-820

Legendre, L., Legendre, P. (1979). Ecologie numerique. 2. Le structure des donnés ecologiques. Masson, Paris

Mackie, G. O., Pugh, P. R., Purcell, J. E. (1987). Siphonophore biology. Adv. mar Biol. 24: 97-262

Masó, M. (1987). Preliminary hydrological results of the 'Spanish Namibian Environmental Cruise' survey, SNEC-II. Colln. scient. Pap. int. Commn SE. Atl. Fish. 14 (2): 113-128

McGowan, J. A. (1967). Distributional atlas of pelagic mol-

This article was submitted to the editor luscs in the California Current region. CalCOFI Atlas 6 $1-218$

McGowan, J. A. (1974). The nature of oceanic ecosystems. In Miller, C. B. (ed.) The biology of the oceanic Pacific Oregon State Univ. Press, Corvallis, p. 9-28

Olivar, M. P. (1990). Spatial patterns of ichthyoplankton distribution in relation to hydrographic features in the Northern Benguela region. Mar Biol. 106: 39-48

Olivar, M. P., Barangé, M. (1990). Zooplankton of the northern Benguela region in a quiescent upwelling period. J. Plankton Res. 12: 1023-1044

Pagès, F. Gili, J. M. (1991). Vertical distribution of epipelagic siphonophores at the confluence between Benguela waters and the Angola Current over 48 hours. Hydrobiologia (in press)

Pugh, P. R. (1974). The vertical distribution of the siphonophores collected during the SOND cruise 1965. J. mar biol. Ass. U.K. 54: 25-90

Pugh, P. R. (1984). The diel migrations and distribution within a mesopelagic community in the North East Atlantic. 7. Siphonophores. Prog. Oceanogr. 13: 461-489

Purcell, J. E. (1982). Feeding and growth of the siphonophore Muggiaea atlantica Cunningham 1892. J. exp. mar Biol. Ecol. 62: 39-54

Purcell, J. E., Kremer, P. (1983). Feeding and metabolism of the siphonophore Sphaeronectes gracilis. J. Plankton Res. 5: 95-106

Raymont, J. E. G. (1983). Plankton and productivity in the Oceans, Vol. 2, Zooplankton. Pergamon Press, Oxford

Russell, F. S. (1935). On the value of certain plankton animals as indicators of water movements in the English Channel and North Sea. J. mar. biol. A.ss. U.K. 20: 309-332

Russell, F. S. (1970). The medusae of the British Isles, Vol. II, Pelagic Scyphozoa, with a supplement to the first volume on Hydromedusae. Cambridge University Press, London

Salat, J., Masó, M., Boyd, A. J. (1991). Water masses distribution and geostrophic circulation of Namibia during April 1986. Contin. Shelf Res. (in press)

Santander, H. (1981). The zooplankton in an upwelling areas off Perú. In: Richards, F. A. (ed.) Coastal upwelling. American Geophysical Union, Washington, D.C., p. 381-399

Shannon, L. V. (1985). The Benguela ecosystem. Part I. Evolution of the Benguela, physical features and processes. Oceanogr mar. Biol. A. Rev. 23: 105-182

Shannon, L. V., Boyd, A. J., Brundrit, G. B., Taunton-Clark, J. (1986). On the existence of an El Nino-type phenomenon in the Benquela System. J. mar. Res. 44: 495-520

Shannon, L. V., Pillar, S. C. (1986). The Benguela ecosystem. Part III. Plankton. Oceanogr. mar Biol. A. Rev. 24: 65-170

Thiriot, A. (1978). Zooplankton communities in the West African upwelling area. In: Boje, R., Tomczak, M. (eds.) Upwelling ecosystems. Springer-Verlag, Berlin, p. 32-61

Totton, A. K. (1965). A synopsis of the Siphonophora. British Museum (Natural History), London

Unterüberbacher, H. K. (1964). The pilchard of S.W. Africa Zooplankton studies in the waters off Walvis Bay with special reference to the Copepoda. Investl Rep. mar Res. Lab. S.W. Afr. 11· 1-42

Manuscript first received: February 5, 1991

Revised version accepted: June 11, 1991 